\title{
Situation Of Infant Mortality And Mother's Health-Seeking Behaviour In Selected Area Of Karachi
}

\author{
Musarrat Iqbal \\ \& \\ Naila Usman Siddiqui \\ Department of Sociology \\ University of Karachi
}

\begin{abstract}
Pakistan has one of the highest Infant mortality rates in the world. Most death takes place as a result of Health seeking behavior of mothers or rather lack of it. This study was aimed at finding out situation of Infant mortalityin low-income areas in Karachi, the capital of Sindh, Pakistan. Due to limited resources this study is restricted to only one locality, Shershah, Karachi. The data was collected from the ever-married women aged 15-49 in sample locality. Detailed information on women's socio-economic background, birth histories and health status was obtained for analysis.

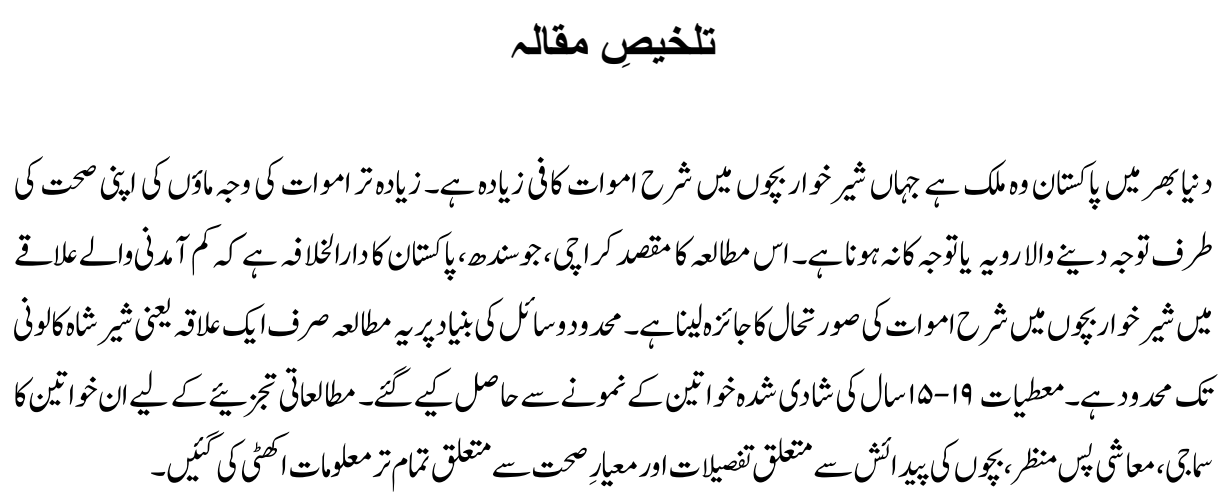

\section{Introduction}

In last few years, social scientists and economists have become critical of GNP and per capita statistics as the major indicator for the level of development, especially in the case of underdeveloped countries. Other more sensitive indicators, which reflect a border range than does the GNP per capita, have begun to be preferred. One of the most important indicators to replace or supplement the GNP per capita concept is the Infant Mortality (IMR) statistics. The importance of this indicator as a reflector of the level of development is further enhanced when one considers the fact that it was one of the three indicators chosen by Morris (1979) for his monumental Physical Quality of Life Index. Thus, the careful observation overtime of the IMR is an important, albeit still crude, sign for the way a country is progressing. And given this importance, it becomes one of the 
main targets, which needs to be addressed by policy makers. However, before one is able to implement measures that bring this rate down, i.e. pushing the 'policy package', it is necessary to study carefully the actual causes that result in the high rate. Seeking explanations for a high level of infant mortality, thus, becomes an important objective. Mortality studies in developing countries are often related to the level of economic development of the nation, or have examined mortality differentials by sociodemographic and environmental factors, both at aggregate and individuals levels within nation (Martin et al, 1983).

According to UNICEF statistics, in Pakistan the infant mortality rate was around 150 to 180 deaths per thousand live births at the time of independence in 1947. This has declined to 96 in 1991, in 2010 it was 70/1000 live births per annum. Neonatal mortality rate was 41 in 2010, mainly due to improved health services and a successful immunization program. Available evidence suggests that slightly more than one-third (36\%) of all deaths occur during infancy in Pakistan. Moreover, one-third of all infant deaths occur within one week of birth. An additional $22 \%$ of deaths occur in the second to fourth week. In other words, more than half of infant deaths are neonatal deaths that occur within four weeks of birth. Much could be done to eliminate some of the causes of neonatal deaths such as short birth intervals and high parity births (PDHS, 1991).

For the most recent five-year period preceding the Pakistan Demographic and Health survey (2006), infant mortality was 78 deaths per 1,000 live births and under-five mortality was 94 deaths per 1,000 live births. The pattern shows that over half of deaths under five occur during the neonatal period, while 26 per centoccur during the post neonatal period. Under-five mortality has declined from 117 in 1986-90 to 94 in 2002-06, a 20 per cent decline in 16 years. Differentials by place of residence show that the underfive mortality rate was 28 percent higher in rural areas than in urban areas (100 vs. 78 deaths per 1,000 live births). As might be expected, rates are lower in major cities than in other urban areas. The major causes of death among children under five are birth asphyxia (accounting for 22 per cent of deaths), sepsis (14 per cent), pneumonia (13 per cent), diarrhea (11 per cent), and prematurity ( 9 per cent). As expected, causes of death are highly correlated with the age at death. Deaths during the neonatal period (first month of life) are almost entirely due to birth asphyxia, sepsis, or prematurity. Deaths in the post neonatal period (age 1-11 months) are mostly due to diarrhea and pneumonia, while the main causes of deaths to children age 1-4 years are diarrhea, pneumonia, injuries, measles, and meningitis. These results support a strong focus on addressing new born deaths and a continued focus on reducing deaths from diarrhea and pneumonia. The Pakistan Demographic and Health Survey (PDHS) .2006-7.

A review of literature on mortality suggests that a gap exist in the knowledge of the factors, particularly operating at the household level that is influential in determining 
mortality of children (Pakistan Demographic and Health Survey, 1991; UNICEF, 1995). There is, therefore a need for a study to understand the health-seeking behavior of mothers; affecting infant mortality.

Infant Mortality Rate (IMR) is defined as the number of infant deaths under one year of age per 1,000 live births. IMR specifically expresses the probability of dying between birth and the first birthday. IMR is divided into neonatal (deaths in the first 4 weeks of life) whereas postnatal (deaths between one to 11 months of age) mortality. Neonatal mortality is determined mainly by prenatal and obstetric factors and post neonatal by environmental factors such as child care, immunity against infections, water and sanitation. In past, infant mortality claimed a considerable percentage of children born, but the rates have significantly declined in the West in modern times, mainly due to improvements in basic health care, though high technology medical advances have also helped. Infant mortality rate is commonly included as a part of standard of living evaluations in economics.

Studies on infant mortality in Pakistan have been estimation of levels, trends and differentials in mortality (Irfan, 1986). The level of infant and child mortality is widely used not only as a demographic measure, but also as an important indicator of the level of health in a society and of its living standard. Like most developing countries, Pakistan has experienced a rapid decline in mortality during the last three decades (Afzal et al., 1988). This decline in mortality has been attributed mainly to health and medical interventions such as immunization and availability of antibiotics to treat infectious diseases; and also to improvements in the socio-economic conditions (Alam and Cleland, 1988). Pakistan's health policy initiatives since independence in 1947 have been concerned with the reduction in infant and child mortality, the development of an extensive public health infrastructure to provide both curative and preventive services, provision of clean drinking water, and a set of social and economic reforms intended to improve the average standards of living (Afzal et al., 1988).

Ahmed, Bhatti\&Bicego ( 1991) examined levels, trends, determinants and differentials in the mortality of infants and children under the age of five, they studied major areas of child survival intervention and found out that it include: (1) control of diarrhoeal disease, (2) management of acute respiratory infection, (3) the Expanded Programme on Immunisation (EPI), and (4) nutrition. Careful examination of changes in the level of infant and child mortality is essential in assessing whether and to what extent such efforts have been effective.

Sathar's (1987) study shows that maternal education was a strong indicator of survival, much more so than paternal education. Similarly, female heads of households increased survival, probably because they control financial allocations. The study suggested that 
rather than attempting to eliminate poverty overall, improvements in maternal education, nutrition, health care facilities and their use, and childbearing and child-rearing methods would do more to improve child survival in Pakistan.

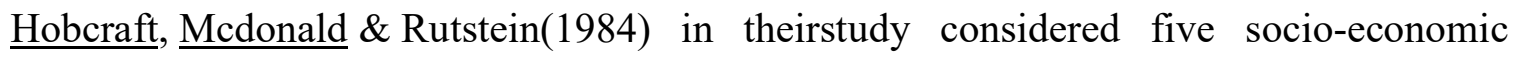
factors of infant and child mortality, using results from World Fertility Survey enquiries in 28 developing countries. They considered differences inthe variables such as mother's education, mother's work status, husband's occupation, husband's education and type of place of residence. The result shows that in general, differences are most strongly associated with only three of the variables considered: mother's education and the husband's occupation and education. Socioeconomic differences increase with age through the first five years of life. Mother's education seems to be particularly strongly associated with infant mortality during the first five years of life in the Asian countries.Hobcraft (1993) points out, that Mother's education may influence child health and mortality through different pathways. Education enhances the acquisition and use of health knowledge

\section{Objectives of the Study}

This study has the following main objectives

1. To collect demographic details of mothers and their families who have suffered from infant mortality.

2. To examine the pattern of health-seeking behavior of mothers residing in sample locality.

3. To examine main factors or reasons of infant mortality in sample locality.

\section{Method and Material}

Major aim of the study is to address the poor health conditions prevailing in some low income localities. Data was collected from respondents living in low-income areas in Karachi, the capital of Sindh, Pakistan. It is the biggest city in the country, with a population of around 15 million and an average annual growth rate of 5\%. Due to limited resources this study is restricted to only one locality, Shershah, Karachi. The data was collected from the ever-married women aged 15-49 in sample localities. Detailed information on women's socio-economic background, birth histories and health status was also obtained. Keeping in view the objectives of the study, interview-cumquestionnaire was prepared and it was translated into Urdu so that field investigators could collect the data easily from the study area. It was decided that sample size of 220 respondents from the universe be taken randomly. At first stage field investigators were trained to collect the data under the supervision of Principle Investigator. We pre-tested 
the questionnaire on $0.5 \%$ respondents from the sample area to check the reliability and validity of the data. The problems faced by the investigators in completing the questionnaires were discussed and thereafter made necessary amendments/changes. The data was clean and edit to control errors at every step while collecting information from the respondents. The database was established regarding the proportion of health population. Problems faced by mothers and their infant were presented in simple tables for analysis and interpretation.

\section{Analysis and Interpretation of Data}

This study was spread over in area of Shershah and a sample of 220 was selected on random basis.

\section{Age of Respondents, their Past Residence and Language Spoken}

A vast majority of respondents were between 21 and 40 years of age $(91.81 \%)$. These most of the respondents were capable to understand our questions and were well aware of the possible problems they were facing. It shows that most of these respondents $(64.53 \%)$ have been living in city whereas only 78 respondents $(35.47 \%)$ migrated from village to the city area (see Table\# 1). Most of the respondents were bilingual, Out of 220 mothers $138(62.72 \%)$ speak Urdu. We thus assume that the respondents' group is quite homogenous.

\section{Type and Size of Family and Income Group}

Poor economic conditions do not allow these families to live in a joint family system and thus majority of them (65.45\%) were living in a nuclear family system (see Table \# 2). The poor earning capabilities are obvious from Table \# 2 where it is quite obvious that 93\% respondents earn less than 6,000 rupees per month.

\section{Educational Level and Occupational Status}

As stated in above paragraph that our respondents have low earning, it could be due to the meager education these people have. Table \# 3 shows that out of 220 respondents a higher proportion (44.54\%) have not received any education and could be classified as "illiterate" people. Table \# 3 also indicates that the poor literacy rate prevails among the spouses as well. Table \# 3 reveals that high proportion $(80 \%)$ respondents were nonworking. The poor economic condition plus a low literacy rate made the health conditions worst in the families. 


\section{Age at Marriage and Age at Birth of the First Child}

Table \#4 shows that almost 41\% respondents got married before reaching the age of 18 while $73 \%$ got married before reaching age of 24 . Male also in Pakistan, get married at early age which give rise to a larger family size. People living in these localities are compelled by social structure and family traditions.

\section{Type of Household Construction}

Table \#5 shows that most of the respondent (56. \%) do not have Pucca house and many of them (48.18\%) have semi Pucca houses. These houses are small and many respondents $(46.36 \%)$ have one or two rooms only. Only smaller families (15.45\%) or more respondents have constructed large houses which consist of five or six rooms.

\section{Household Facilities}

Table \#6 shows that (90\%) respondents have access to natural gasfor their kitchens and $100 \%$ have electricity. These facilities eases their living and decrease pollution, improves environmental condition and leave live for these respondent to do some other work, if they wish so. Unlike natural gas and electricity other facilities like refrigerator, TV, Telephone, VCR are not too common in these localities, thoughmost people own cell phone now a days.

\section{Sanitation and Water Facilities}

Table \# 7 reveals that almost $80 \%$ of our respondents keep garbage in open containers. Garbage disposal is a problem for residents for these localities. Access to clean water is a right of every citizen, yet it is far away from these residents.

\section{Health Education}

It was observed at Table \# 8 that almost 90\% of our respondents (196) do not regularly spend a particular amount on health problems. Illiteracy plays a vital role in this ignorant attitude. Vast majority of our respondents (51\%) received health knowledge after consulting doctors. There should be more programs and gathering arranged by the community member where people can learn more about health hazard and possible preventive measures.

\section{Ideal and Desired Number of Children}

Son preference is evident in the result .74\%respondents (74\%) do not wish any more girls in their family. None of them wanted more than 4 or more girls but $35 \%$ wanted to have more than 4 boys. 


\section{Number of Alive and Still Births}

It is alarming and need specific measures when we look at Table \# 10 we find that the $66.36 \%$ families has less than four alive births and only $14.53 \%$ had more than 5 live births. The poor economic condition can easily portray the conditions in which their children and the entire family must be living.

\section{Duration of Sickness of Diseased Infant}

The situation is not so good and does not provide a good picture when we look at Table \# 11 that all the 220 respondents have had faced infant mortality.Among the 150 respondents $(68.81 \%)$ had seen at least one infant died in their family. Diarrhea was major cause of death of infants which is due to unclean contaminated water.

\section{Awareness of Health Conditions}

Feedback revealing information regarding health awareness is also very poor. Table \# 12 shows that $57 \%$ respondents were partly satisfied with their health condition during pregnancy, very few were concerned of their diet . 33\% had blood pressure either low or high or they were anemic during pregnancy.

\section{Vaccination Program}

Our study shows that $68.18 \%$ (150) respondents have followed the vaccination program thus ensure a good healthy life for their children while $10.90 \%$ follow the vaccination program casually (see Table \#13). Unhygienic living condition, mother's malnutrition and high rate of fertility were the major causes of infant mortality, identified by respondents.

\section{Recommendations}

In our country considerable progress against infant mortality, neo natal mortality can be accomplished through the implementation of basic public health measures. Public health department should play its role so it could reduce infant deaths due to diarrhea and infectious disease. Proper trained medical voluntaries should be hired to work in the community. Volunteers should provide education to parents that a smaller healthier family is far better than a large unhealthy family. Proper vaccinations should provide in specified time span at prescribed time to understand that duration are extremely essential. Any negligence at any stage may cause heavy health related problems while ultimate could result in a retarded human being. Different organizations working in the community need to address the problems through advertisement and easy accessibility 
92 Situation of Infant Mortality and Mother's Health-Seeking Behaviour in Selected Area of Karachi

mass media.More health related Centre especially with maximum facilities should be opened in less privileged areas. Nurses and community workers should contact people regularly, encourage and educate them about health related problems, their causes and their after effects. This might be a long journey but would be a very fruitful for future generation. The spread of health knowledge cannot be fast without the support of the influential people of the area. They must be contacted in advance, communicated and then motivated to guide the residents. The residents should strictly follow the health education codes. If the elders of the society use their influences it could be done quite successfully. For example cleanliness is an acute problem in such localities if the elders and influential people decide that appropriate cleaning measures should be used and if they compel resident to keep area clean, many people would response. We also suggest that government and NGOs working in their particulars once should work hard at publicize the correct effect of infants mortalities could face due to the negligence of their aware of the deprecation of negligence at these early stages of infants deaths.

\section{Bibliography}

Afzal, M.T; A. Raja and A. Muhammad (1988). Some Differentials in infant and child mortality risks in Pakistan 1962-1986.The Pakistan Development Review, 27:2,635-642.

Ahmed, T. and B. Monsoor-ul-Hssan (1991).Infant and child mortality.Chapter in Pakistan Demographer Health Survey, 111-123.

Alam, A. and J. Cleland (1988).Infant and child mortality: Trends and determinants in IqbalAlam and Betzy Dinesen (ed.). Fertility in Pakistan: A review of findings from the Pakistan Survey. Voorburge: International Statistical Institutes, 187-212.

Caldwell, J.C. (1979). Education as a factor in mortality decline: An examination of Nigerian data,Population Studies, 33:2, 395-413.

Caldwell, J.C.; P.J. Reddy and P. Caldwell (1983).The social component of mortality decline: An investigation in South India employing alternative methodologies.Population Studies 37:2,185-205.

Hobcraft, J.N; J.W. Mcdonald, and S.O. Rutsetein (1984).Socio Economic factors in infant and child mortality: Across-national comparison.Population Studies, $38: 2,193-223$.

Irfan, M.M. (1986). Mortality trends and patterns in Pakistan, ESCAP, UN.Asian Population Studies Series \#75. 
Khan, Z. (1991). Are breastfeeding pattern in Pakistan changing. The Pakistan Development Review, 30:3,297-311.

Martin, L.G., J. Trussell, F.R. Salvail, and N.M. Shah (1983).Covariates of child mortality in Philippines, Indonesia and Pakistan: An analysis based on hazard model. Population Studies, 37:4,417-432.

Morris, David. (1979), "Measuring the Conditions of the World Poor, the Physical Quality of Life Index”, Pergaman Press, New York.

Pakistan Devolpment and Health Survey, (1991).Pakistan Demographic and Health Survey, 1990.Macro/IRD and National Institute of Population Studies, Pakistan.

Rutstein, SO. (1984). Infant and child mortality: Levels trends and demographic differentials. WFS Comparative Studies 24 Vooburg, Netherlands: International Statistical Institutes.

Sathar, Z.A. (1987). Seeking explanations for high levels on infant mortality in Pakistan.The Pakistan Development Review, 26:1,55-70.

Sathar, Z.A. (1987). Infant and child mortality in Pakistan, Some trends and differentials.Journal of Biosocial Science, 17:3,351-359.

UNICEF (1995).State of the world's children.1986-1995.UNICEF, New York, USA.

UNICEF(2011).availableathttp://www.unicef.org/infobycountry/pakistan_pakistan_statist ics.html .Retrieved on July 24th,2012. 
94 Situation of Infant Mortality and Mother's Health-Seeking Behaviour in Selected Area of Karachi

Table: 1

Frequency and Percentage Distribution of Respondents by their Age, Past Residence and Language Spoken

\begin{tabular}{|l|c|c|}
\hline & Frequency & Percentage (\%) \\
\hline Age Group (Years) & & \\
\hline Less than 20 & 8 & 04 \\
\hline $21-30$ & 136 & 62 \\
\hline $31-40$ & 66 & 30 \\
\hline 41 and above & 10 & 04 \\
\hline Past Residence & & \\
\hline City & 142 & 65 \\
\hline Village & 78 & 35 \\
\hline Language Spoken & & \\
\hline Urdu & 138 & 63 \\
\hline Punjabi & 24 & 11 \\
\hline Pushto & 12 & 05 \\
\hline Barohi & 04 & 02 \\
\hline Siraiki & 14 & 06 \\
\hline Sindhi & 28 & 13 \\
\hline
\end{tabular}


Table: 2

Frequency and Percentage Distribution of Type and Size of Family and Income

\begin{tabular}{|l|c|c|}
\hline \multicolumn{1}{|c}{ Group } & Prequency & \\
\hline Type of Family & & 65 \\
\hline Nuclear & 144 & 35 \\
\hline Joint & 76 & \\
\hline Size of Family & & 05 \\
\hline 2-4 members & 04 & 39 \\
\hline $5-7$ members & 30 & 24 \\
\hline $8-10$ members & 18 & 26 \\
\hline $11-13$ members & 20 & 06 \\
\hline $14 \&$ above Members & 04 & 13 \\
\hline Income Level (Rupees) & & 36 \\
\hline Less than 2000 & 28 & 26 \\
\hline $2000-3000$ & 78 & 08 \\
\hline $3000-4000$ & 58 & 10 \\
\hline $4000-5000$ & 18 & 07 \\
\hline $5000-6000$ & 22 & \\
\hline 6000 and above & 16 & \\
\hline
\end{tabular}


Table: 3

Frequencies and Percentage Distribution of Respondents and Their Spouses' Educational Level and Occupational Status

\begin{tabular}{|l|c|c|}
\hline & Frequency & Percentage (\%) \\
\hline Educational Status of Respondent & & 44 \\
\hline Illiterate & 98 & 18 \\
\hline Primary & 40 & 21 \\
\hline Matriculation & 46 & 10 \\
\hline Intermediate & 22 & 05 \\
\hline Graduate & 10 & 02 \\
\hline Post Graduate & 04 & \\
\hline Educational Status of Spouse & & 27 \\
\hline Illiterate & 60 & 36 \\
\hline Primary & 80 & 18 \\
\hline Matriculation & 40 & 06 \\
\hline Intermediate & 12 & 06 \\
\hline Graduate & 14 & 04 \\
\hline Post Graduate & 08 & 03 \\
\hline No Response & 06 & 80 \\
\hline Employment Status of the Respondent & & 02 \\
\hline Housewife & 176 & 09 \\
\hline Govt. Service & 04 & 09 \\
\hline Private Service & 20 & \\
\hline Labor & 20 & 14 \\
\hline Employment Status of Spouse & & 35 \\
\hline Govt. Service & 30 & 08 \\
\hline Private Service & 78 & 43 \\
\hline Business & 97 & \\
\hline Labour & & \\
\hline
\end{tabular}


Table: 4

Frequencies and Percentage Distribution of Respondents and Their Spouses' Age at Marriage and Age at Birth of the First Child

\begin{tabular}{|l|c|c|}
\hline & Frequency & Percentage (\%) \\
\hline Respondent's Age at Marriage & & 41 \\
\hline 14-18 Years & 90 & 32 \\
\hline 19-23 Years & 70 & 16 \\
\hline 24-28 Years & 36 & 09 \\
\hline 29-33 Years & 20 & 02 \\
\hline 34-38 Years & 04 & 04 \\
\hline Spouse Age at Marriage & 04 & 16 \\
\hline 14-18 Years & 36 & 47 \\
\hline 19-23 Years & 104 & 23 \\
\hline 24-28 Years & 50 & 10 \\
\hline 29-33 Years & 22 & \\
\hline 34-38 Years & & 19 \\
\hline $\begin{array}{l}\text { Age of the Respondents at Birth } \\
\text { of the First Child }\end{array}$ & 42 & 76 \\
\hline 15-19 Years & 168 & - \\
\hline 20-29 Years & 10 & 05 \\
\hline 30-39 Years & - & \\
\hline 40-49 Years & & \\
\hline
\end{tabular}


98 Situation of Infant Mortality and Mother's Health-Seeking Behaviour in Selected Area of Karachi

Table: 5

Frequencies and Percentage Distribution of Households by Type of Construction and Number of Rooms

\begin{tabular}{|l|c|c|}
\hline & Frequency & Percentage (\%) \\
\hline Type of Construction & & \\
\hline Kutcha / Wooden & 18 & 08 \\
\hline Semi-Pucca & 106 & 48 \\
\hline Pucca & 96 & 44 \\
\hline Number of Rooms & & \\
\hline $1-2$ & 102 & 46 \\
\hline $3-4$ & 84 & 38 \\
\hline $5-6$ & 34 & 16 \\
\hline
\end{tabular}

Table: 6

Frequencies and Percentage Distribution by Households Facilities

\begin{tabular}{|l|c|c|}
\hline & Frequency & Percentage (\%) \\
\hline Electricity & & 100 \\
\hline Yes & 220 & - \\
\hline No & - & 90 \\
\hline Sui Gas & 200 & 10 \\
\hline Yes & 20 & \\
\hline No & & 10 \\
\hline Telephone & 22 & 90 \\
\hline Yes & 198 & 08 \\
\hline No & & 92 \\
\hline Refrigerator & 18 & \\
\hline Yes & 202 & 18 \\
\hline No & & 82 \\
\hline TV & 40 & \\
\hline Yes & 180 & 05 \\
\hline No & & 95 \\
\hline VCR & 10 & 23 \\
\hline Yes & 210 & 77 \\
\hline No & 50 & \\
\hline Radio/Tape Recorder & 170 & \\
\hline Yes & & \\
\hline No & & \\
\hline
\end{tabular}


Table: 7

Frequencies and Percentage Distribution of Households by Sanitation and Water Facilities

\begin{tabular}{|l|c|c|}
\hline & Frequency & Percentage (\%) \\
\hline Toilet Facilities & & 65 \\
\hline Flush & 144 & 06 \\
\hline Bucket & 14 & 25 \\
\hline Pit Latrine & 54 & 04 \\
\hline No Facility & 08 & \\
\hline Garbage Container & & 21 \\
\hline Covered Bin & 46 & 79 \\
\hline Open Container & 174 & 06 \\
\hline Garbage Disposal & & 12 \\
\hline In the Area & 14 & 06 \\
\hline Outside the Area & 26 & 76 \\
\hline Burn & 12 & \\
\hline Handover to Sweeper & 168 & 25 \\
\hline Source of Drinking Water & & 10 \\
\hline Private Pipe & 56 & 35 \\
\hline Public Tape & 22 & 30 \\
\hline Sprig/Well & 76 & \\
\hline Tanker & 66 & 38 \\
\hline Purifying Water & & 62 \\
\hline Yes & 84 & \\
\hline No & 136 & \\
\hline Purification Method & & \\
\hline Boiling & 24 & \\
\hline Chemical & & \\
\hline
\end{tabular}


100 Situation of Infant Mortality and Mother's Health-Seeking Behaviour in Selected Area of Karachi

Table: 8

Frequencies and Percentage Distribution by Health Education

\begin{tabular}{|l|c|c|}
\hline & Frequency & Percentage (\%) \\
\hline $\begin{array}{l}\text { Spent Income on Health } \\
\text { (Monthly) }\end{array}$ & & \\
\hline Yes & 24 & 11 \\
\hline No & 196 & 89 \\
\hline $\begin{array}{l}\text { Amount Spent on Health } \\
\text { (Monthly in Rupees) }\end{array}$ & & \\
\hline $100-300$ & 12 & 50 \\
\hline $400-600$ & 04 & 17 \\
\hline $700-900$ & 08 & 33 \\
\hline Received Health Education & & 65 \\
\hline Yes & 144 & 35 \\
\hline No & 76 & 04 \\
\hline Source of Health Education & & 10 \\
\hline Friends & 06 & 21 \\
\hline Relatives & 14 & 51 \\
\hline Community Members & 30 & 14 \\
\hline Doctors & 74 & 12 \\
\hline Mass Media & 20 & 10 \\
\hline Rate Health Condition & & 65 \\
\hline Excellent & 26 & 09 \\
\hline Very Good & 142 & \\
\hline Good & 20 & \\
\hline Bad & 10 & \\
\hline Poor & & \\
\hline & & \\
\hline
\end{tabular}


Table: 9

Frequencies and Percentage Distribution by Ideal and Desire Number of Children

\begin{tabular}{|c|c|c|}
\hline & & Dorrontore (0/) \\
\hline \multicolumn{3}{|c|}{ Ideal Number of Boys } \\
\hline $1-2$ & 138 & 63 \\
\hline $3-4$ & 58 & 26 \\
\hline More than 4 & 24 & 11 \\
\hline \multicolumn{3}{|c|}{ Ideal Number of Girls } \\
\hline $1-2$ & 174 & 79 \\
\hline $3-4$ & 46 & 21 \\
\hline More than 4 & Nil & Nil \\
\hline \multicolumn{3}{|c|}{ Desire More Boys } \\
\hline None & 24 & 11 \\
\hline $1-2$ & 112 & 51 \\
\hline $3-4$ & 78 & 35 \\
\hline 5 and More & 06 & 03 \\
\hline \multicolumn{3}{|c|}{ Desire of More Girls } \\
\hline None & 162 & 74 \\
\hline $1-2$ & 54 & 24 \\
\hline $3-4$ & 04 & 02 \\
\hline 5 and More & Nil & Nil \\
\hline \multicolumn{3}{|c|}{$\begin{array}{l}\text { At Least Preferred Birth } \\
\text { Duration }\end{array}$} \\
\hline 1 Year & 30 & 13.63 \\
\hline 2 Years & 96 & 43.63 \\
\hline 3 Years & 90 & 40.90 \\
\hline 4 Years & 04 & 1.81 \\
\hline \multicolumn{3}{|c|}{$\begin{array}{l}\text { At Most Preferred Birth } \\
\text { Duration }\end{array}$} \\
\hline 1 Year & Nil & Nil \\
\hline 2 Years & 74 & 34 \\
\hline 3 Years & 114 & 52 \\
\hline 4 Years & 32 & 14 \\
\hline
\end{tabular}


102 Situation of Infant Mortality and Mother's Health-Seeking Behaviour in Selected Area of Karachi

Table: 10

Frequencies and Percentage Distribution by Number of Alive and Still Births

\begin{tabular}{|l|c|c|}
\hline & Frequency & Percentage (\%) \\
\hline Number of Children & & \\
\hline or Less & 86 & 39 \\
\hline $3-4$ & 88 & 40 \\
\hline $4-5$ & 26 & 12 \\
\hline More than 6 & 20 & 09 \\
\hline Number of Alive Births & & \\
\hline Less than 2 Births & 60 & 27 \\
\hline 2-3 Births & 86 & 39 \\
\hline 4-5 Births & 42 & 19 \\
\hline More than 5 Births & 32 & 15 \\
\hline Number of Still Births & & 66 \\
\hline None & 144 & 27 \\
\hline 1-2 & 60 & 07 \\
\hline 3 or More & 16 & \\
\hline
\end{tabular}


Table: 11

Frequencies and Percentage Distribution by Number, Ages and Duration of Sickness of the Diseased Infant

\begin{tabular}{|l|c|c|}
\hline & Frequency & Percentage (\%) \\
\hline Number of Infant Mortality & & 69 \\
\hline 1 Child & 150 & 31 \\
\hline 2 or More Children & 70 & 35 \\
\hline Age of Deceased Infant & & 30 \\
\hline Less than 3 Months & 76 & 21 \\
\hline 3-4 Months & 66 & 05 \\
\hline 5-6 Months & 46 & 09 \\
\hline 7-8 Months & 12 & \\
\hline 8-12 Months & 20 & 43 \\
\hline Duration of Sickness of Deceased & & 33 \\
Infant & & 14 \\
\hline Less than 3 Months & 94 & 10 \\
\hline 3-4 Months & 72 & \\
\hline 5-6 Months & 30 & 34 \\
\hline 7 and above Months & 24 & 30 \\
\hline Cause of Death & & 21 \\
\hline Phenomena & 76 & 15 \\
\hline Diarrhea & 66 & \\
\hline Fever & 46 & 32 \\
\hline Fits & & \\
\hline
\end{tabular}


104 Situation of Infant Mortality and Mother's Health-Seeking Behaviour in Selected Area of Karachi

Table: 12

Frequency and Percentage Distribution of Respondents by Health, diet and Sickness Conditions during the Pregnancy of the Deceased Infant

\begin{tabular}{|l|c|c|}
\hline $\begin{array}{l}\text { Satisfied with Health } \\
\text { Conditions during Pregnancy }\end{array}$ & Frequency & Percentage (\%) \\
\hline Fully & 70 & \\
\hline Partly & 126 & 32 \\
\hline Not at All & 24 & 57 \\
\hline Concerned of Diet & 76 & \\
\hline Yes & 144 & 35 \\
\hline No & & 65 \\
\hline Type of Diet & 21 & 28 \\
\hline Milk & 19 & 25 \\
\hline Meat & 12 & 16 \\
\hline Eggs & 24 & 31 \\
\hline Fruits & & \\
\hline Reasons for Lack of Diet Care & 64 & 44 \\
\hline Low income & 18 & 12 \\
\hline Inflation & 22 & 15 \\
\hline Lack of Information & 26 & 18 \\
\hline Lack of Availability & 14 & 10 \\
\hline Joint Family & & \\
\hline Fell in Disease During \\
Pregnancy & & 33 \\
\hline Yes & 72 & 67 \\
\hline No & 148 & 25 \\
\hline Nature of Disease & & 31 \\
\hline High Blood Pressure & 18 & 44 \\
\hline Low Blood Pressure & 22 & \\
\hline Anemic & 32 & \\
\hline
\end{tabular}


Table: 13

Frequencies and Percentage Distribution by Vaccination Program for the Deceased

\begin{tabular}{|l|c|c|}
\hline \multicolumn{1}{|l}{ Infant } & Frequency & Percentage (\%) \\
\hline Follow Vaccination Program & & \\
\hline Yes & 150 & 68 \\
\hline To Some Extent & 24 & 11 \\
\hline No & 46 & 21 \\
\hline Reasons not Follow & & \\
Vaccination Program & & 61 \\
\hline Lack of Awareness & 28 & 09 \\
\hline Financial Problems & 04 & 30 \\
\hline Distance from Center & 14 & 17 \\
\hline Causes of Infant Mortality & & 10 \\
\hline Lack of Education & 37 & 13 \\
\hline Lack of Medical Facilities & 22 & 21 \\
\hline Lack of Awareness & 28 & 26 \\
\hline High Fertility Rate & 45 & 13 \\
\hline Malnutrition of Mothers & 58 & \\
\hline Unhygienic Conditions & 30 & \\
\hline
\end{tabular}

Dr. Musarrat Iqbal was Associate Professor in the Department of Sociology University of Karachi.

Dr. Naila Usman Siddiqui is Assistant Professor Department of Sociology University of Karachi. 